$\begin{array}{ll} & \text { Etnográfica } \\ \text { etnográfica } & \text { Revista do Centro em Rede de Investigação em }\end{array}$

Antropologia

vol. 21 (1) | 2017

Vol. 21 (1)

\title{
Bollywood in Portugal: watching and dancing practices in the construction of alternative cultural identities
}

Bollywood em Portugal: a construção de identidades culturais alternativas entre audiências e praticantes de dança

Inês Lourenço

\section{(2) OpenEdition}

\section{Journals}

Electronic version

URL: https://journals.openedition.org/etnografica/4863

DOI: 10.4000/etnografica.4863

ISSN: 2182-2891

\section{Publisher}

Centro em Rede de Investigação em Antropologia

Printed version

Date of publication: 1 February 2017

Number of pages: $175-202$

ISSN: 0873-6561

\section{Electronic reference}

Inês Lourenço, "Bollywood in Portugal: watching and dancing practices in the construction of alternative cultural identities", Etnográfica [Online], vol. 21 (1) | 2017, Online since 11 March 2017, connection on 10 February 2022. URL: http://journals.openedition.org/etnografica/4863 ; DOI: https:// doi.org/10.4000/etnografica.4863

\section{(c) (7) \&}

Etnográfica is licensed under a Creative Commons Attribution-NonCommercial 4.0 International License. 


\section{Bollywood in Portugal: watching and dancing practices in the construction of alternative cultural identities}

\section{Inês Lourenço}

The impact of Bollywood cinema among Portuguese viewers is an unknown reality in the surrounding society. Usually associated to the communities of Indian origin, the consumption of this kind of cinema also occurs among people from various sectors of the Portuguese population that although not related to each other, have in common the habit of watching Indian films in private, away from the suspicious and stereotyped looks from their relatives and friends. In the meantime, Bollywood dance, the performance inspired by the Hindi cinema choreographies, is growing. The increase of its practitioners reveals an interest in cultural references associated with India and its popular culture, functioning Bollywood dance as an alternative dance practice, generating wellbeing. This paper focuses on the anthropological analysis of both popular Indian cinema audiences and the increasing practice of Bollywood dance in Portugal, exploring the processes of demand for wellbeing based on cultural references from Indian popular culture. Although with different features, these two ethnographic examples represent creative and alternative cultural processes, through which new identities arise, framed in old orientalist ideas.

KEYWORDS: India, Portugal, Bollywood, cinema, dance, consumption, neo-Orientalism.

Bollywood em Portugal: a construção de identidades culturais alternativas entre audiências e praticantes de dança - O impacto do cinema de Bollywood entre os espetadores portugueses é uma realidade desconhecida da sociedade envolvente. Geralmente associado às comunidades de origem indiana, o consumo deste tipo de cinema também ocorre entre pessoas pertencentes a diferentes setores da sociedade portuguesa, sem qualquer ligação direta com a Índia e que, apesar de não se relacionarem entre si, têm em comum o hábito de ver cinema indiano em privado, longe dos olhares suspeitos dos seus amigos e familiares. Ao mesmo tempo, a dança Bollywood, a performance inspirada nas coreografias do cinema de língua hindi, está a atrair cada vez mais praticantes portugueses. Este fenómeno revela um progressivo interesse pelas referências culturais associadas à Índia e à sua cultura popular, funcionando a dança Bollywood como uma prática de dança alternativa, geradora de bem-estar. Este artigo baseia-se na análise antropológica das audiências de cinema popular indiano e da prática de dança Bollywood em Portugal, explorando os processos de procura de bem-estar com base nas referências da cultura popular indiana. Apesar de apresentarem diferentes caraterísticas, estes dois casos etnográficos representam processos culturais criativos e alternativos, através dos quais surgem novas identidades, enquadradas em ideias do velho orientalismo. 
PALAVRAS-CHAVE: Índia, Portugal, Bollywood, cinema, dança, consumo, neo-orientalismo.

LOURENÇO, Inês (ines.lourenco@iscte.pt) - Instituto Universitário de Lisboa (ISCTE-IUL), Centro em Rede de Investigação em Antropologia (CRIA-IUL), Portugal.

\section{INTRODUCTION}

A new Orientalism, apparently invigorated by globalization, is currently associated with consumption practices that first emerged in the 1990s in correspondence with the emergence of "Indo-chic" (Maira 2007: 221). In this context, Bollywood film industry can be perceived as transmitting images of India with potential for the reification of Indian culture and traditions. ${ }^{1}$ Edward Saïd's Orientalism (1995 [1978]) applies the concept of Western cultural hegemony to the Middle East in particular, but may also extend to other regions of Asia, such as India. Similarly, New Orientalism ${ }^{2}$ suggests a renewed search for the exotic that awakes in the Western world ambiguous feelings of desire and fear relating to the East, in this case synonymous with a representation of the "other."

This paper intends to explore Bollywood consumption in Portugal - specifically, its film and dance versions -, processes of cultural borrowings that result in new and innovative forms of identity construction, and to understand how far Orientalism influences them. ${ }^{3}$ With regard to cultural representations of India, New Orientalism emerges deeply associated with consumption, as demonstrated by Graham Huggan's expression “consuming India” to designate the phenomenon under which India became a capital producer of export goods (Huggan 2001: 67). In fact, most of the goods that originate in India are currently tradable, albeit the fact that in essence many are transformed or even custom-made for Western buyers, using designs very distant from their original form or utility. In brief, these goods have been reinvented for Orientalist consumption, which is based on essentialist constructions and on a fictional India.

I Bollywood is the informal name used to refer to the Hindi film industry, based in Mumbai, resulting in the fusion between Bombay, the city of Mumbai's old name, and Hollywood, the center of American film industry.

2 Several ideas emerged to characterize the contemporary resurgence of new forms of Orientalism. This is the case of the concepts of Neo-Orientalism (Bohemer 1998), New Orientalism (Toor 2000), and Re-Orientalism (Lau and Mendes 2011).

3 I would like to thank Diana Rego for her reading and comments on this text, for her generosity and inspiration. 
Portuguese consumption of goods originated in India shares the global trend in which India has a strong cultural presence (seen in the proliferation of Indian restaurants, clothing styles and decor as well as wellness therapies and yoga), but yet India continues to be daily stereotyped, its real cultural identity mystified and exoticized. The Portuguese colonial past propelled the Indian immigration but the visibility of Indian-origin people in Portugal is recent, particularly in the Lisbon Metropolitan Area and also in Porto, although many Indian communities have been established in this country for more than three decades. Cultural activities that juxtapose people of Indian origin with other sectors of the Portuguese population generate mutual intersections, which currently unleashes the growing impact of Indian cultural references in Portuguese urban and cosmopolitan society.

As in other contexts of the Indian Diaspora, Portuguese Indian origin communities contributed to the "consuming India" phenomenon. With regard to Indian cinema, and particularly Bollywood, its consumption in Portugal occurs in a subtler level, but it is nevertheless a growing phenomenon, coupled with the consumption of other cultural products that are directly or indirectly associated with it - for example: dance, food, clothing, and the increasingly famous Bollywood parties.

This paper focuses on the cultural practices associated with the consumption of Bollywood in Portugal. This phenomenon will be analyzed based on two empirical studies focusing on Bollywood film audiences and Bollywood dance practice. This anthropological approaches aim to explore the processes of cultural cosmopolitan construction of global media consumption, particularly in application to Bollywood cinema and its cultural appropriations. There is admittedly a proliferation of literature on the impact of Bollywood abroad, which is circumscribed to its impact on diasporas, particularly young people of South Asian descent (cf. Acharya 2004; Bandyopadhyay 2008; Battacharya 2004; Ciecko 2001; Datta 2008; Dudrah 2006; Ebrahim 2008; Kao and Do Rozario 2008; Shresthova 2008; Tirumala 2009). In contrast, this paper aims to reflect on the impact of Bollywood on non-Indian origin audiences. In fact, Bollywood audiences are increasingly global, and Bollywood has long transcended the context of South Asian diasporas. David Novak showed how the reception of Bollywood by these diverse audiences is not always based on the movies themselves but rather on some particular elements, such as music, clothing, and performances (Novak 2010: 40). According to Novak, relevance should be given to the role of the subjects in these circulation and globalization processes and their consequent cultural appropriation (Novak 2010: 41).

Rajinder Dudrah (2006) proposed an interdisciplinary approach to the popular Hindi cinema, combining sociology, film and media studies, and cultural studies. According to Dudrah, Denzin's cinematic culture approach (1991, 1995), based on Mills' sociological imagination (2000 [1959]), is crucial to 
understand these dynamics. This is only possible through engagement with current social subjects (Dudrah 2006: 26). The fascination held by Western industries for Bollywood, as well as Bollywood's unprecedented relationship with its audiences (Dudrah 2006: 36) confirm the status of global entertainment that Bollywood has acquired in recent years. In Portugal the audiences of Indian cinema are increasing, coupled with the growing visibility of India and its diasporas, and also contemporary cosmopolitan fashion, which drives consumption of India in different areas. In the context of the great variety of Indian cinemas (Telugu, Bengali, among many others), Inda's most popular cinema, Bollywood, offers its audiences fantasy, wellbeing, and pleasure. These are consumed in tandem with film narratives often received as stereotypical and romantic representations of India.

Similarly, recent years have witnessed a growing public visibility of Indian cultural expressions in Portugal, in the field of classic dance styles such as Bharatnatyam, Kathak or Odissi, as well as in the most popular and global form, Bollywood dance. Bollywood films' song and dance components are its brand image for Western audiences. Although unaware of the plot, actors and actresses' names, or even the names of the films themselves, Western audiences have had contact with the musical sequences, which are deliberately created to be detached from the movies. Moreover, just as classical dances, whose function is to narrate mythological stories, musical sequences of Bollywood maintain a narrative purpose.

This attraction for kitsch influenced contemporary Western fashion, and many Indian cultural references have become commodities, in a context where "aesthetic of excess enters mainstream culture as a trend that does not in any way disturb or challenge dominant norms but merely supplements it with some exotic color" (Gopal and Moorti 2008: 44). Kitsch, colorful, and exotic elements are found in the practice of Bollywood dance. The demand for this dance by nonSouth Asian-origin people is a recent phenomenon of Western cities (Shresthova 2011: 141), coupled with an increasing visibility of Hindi cinema and, as a consequence of globalization, the most recent media technologies. Inspired by Hindi cinema, Bollywood dance is nevertheless a unique field of artistic creativity and cultural alternatives: "Bollywood song and dance create a contact zone, but the body itself becomes a borderland where improvisational and interactive elements help reconstitute subjectivities" (Gopal and Moorti 2008: 47).

The practices of cultural appropriation (Novak 2010: 41) lead to the creation of new social subjects through the construction of new cultural identities. This paper analyzes the consumption of Bollywood as a phenomenon of cultural appropriation and recreation, and aims to understand both the reasons why individuals consume cultural goods, and the impact that these have - or do not have - in their lives. In this context, it aims to answer the following questions: Who are the audiences of Bollywood cinema in Portuguese urban 
society? What are their perceptions of India and what do they search for in this kind of cinema? What is Bollywood dance, and who are its practitioners? How is it received and appropriated by its practitioners? Finally, are these practices of cultural consumption a New-Orientalist phenomenon?

Several authors reported that the appropriation of "other" cultural references takes place through processes that recover the old Orientalism ideas. Called Neo- or New-Orientalism, these processes were also considered forms of Orientalist hybridity (McGee 2012: 232) that do not involve a complete immersion in the Eastern cultural practices but rather develop in conjunction with other cultural elements and lifestyles. Considered by some authors universalist humanism (Maira 2003) or mediated representations of the orient (McGee 2012: 233), this phenomenon will be discussed in view of the Portuguese context, aiming to contribute to the debate on cultural appropriations resulting from the globalization of consumer culture.

\section{METHODOLOGY}

Gray showed how participant observation with real audiences - distinct from those of quantitative studies - creates a personal connection with viewers that is reflected in the information collected and, in a deeper and more accurate view, different from the voiceless masses of the Frankfurt School (Gray 2010: 116). Thus, anthropology is very useful in understanding audiences, allowing for the articulation of what a certain audience makes of a movie or television show in the surrounding social and cultural context (Gray 2010: 122). In this case, we cannot neglect the contribution of cultural studies in establishing a relationship between forms of popular culture and the broader topics of political ideology, gender, and the relationship between culture and power, in which Stuart Hall had a decisive role (see Hall 1980).

To better understand the process of consumption of Hindi cinema in Portugal, as well as the social uses associated with it, I began a search for potential followers of this film genre, a majority of whom were found via Internet, through specialized blogs on this theme; the Internet played a key role in this process, given the absence of a dissemination circuit of Indian cinema in Portugal. Finding the participants of this project spread over different parts of the country, I resorted to a multi-situated ethnography, and geographically extended this research work that initially should focus only on the city of Lisbon.

Several methodological tools were used in this research: online contacts, as many members of this audience were found via Internet, i.e., through blogs, email exchange, and Facebook chat. The difficulty in contacting these audiences led me to turn to the Internet. Initially I contacted one of the authors of the blog Grand Masala, which is dedicated to the dissemination of Indian 
cinema, as well as cultural activities related to it. ${ }^{4}$ The contribution of this blog for this research was central. Through it my project as well as the request for participants was publicized, giving me access to the interlocutors of this research. The Internet was thus a privileged means to access Portuguese Indian popular cinema audiences, since this is a resource used by many of these individuals, in particular for downloading films. ${ }^{5}$

The fact that I only was able to find them through this strategy corroborated that Bollywood is a predominantly private consumption, as it will be further demonstrated. Informal interviews and participant observation were the techniques of the ethnographic methodology used. The empirical data, collected mainly through ethnographic research and interviews, also included visits to stores selling Indian films, collecting information from vendors, and attempted contact with potential fans of Indian cinema.

The interactions with these interlocutors were conducted in different ways. Where personal and frequent contact was possible, I resorted to semi-structured and informal interviews. In some cases, the interviews were complemented by Internet searches and viewing of film clips. For participants located over large geographical distances, as well as for those who lacked the time to meet in person, contact was maintained through the exchange of emails or conversations via Internet chat. The interest my interlocutors showed in participating in this project, even those located in distant places, thus influenced me to make use of these resources.

In the case of Bollywood dance, I approached participants through attending the dance classes myself. Participant observation, supplemented by interviews, was the method used. In Lisbon I was invited to participate in a trial lesson and to assist a dance company rehearsal directed by the teacher and choreographer Diana Rego. I followed up the invitation to participate in classes as an approximation to the students and also as a means of - in this case literally - participant observation. Thus, in addition to participating in the classes, I also resorted to "changing room ethnography," taking advantage of the gathering space before and after classes to establish contact with the dance students. These moments were a complement to informal interviews, accomplished outside of the dance school and gym areas. Again, online communication methods - especially email and Facebook - had a determining role in maintaining contact with the interlocutors.

4 See $<$ http://grandmasala.blogspot.pt $>$ (last access in January 2017).

5 Some issues related to qualitative research through the Internet have already been discussed. Bedows shows how the Internet provides "its own and unique set of methodological issues" (2008: 135) but simultaneously new constraints, leading to the need for developing new techniques to address these new issues. 


\section{WATCHING HINDI CINEMA AND THE CONSUMPTION OF ALTERNATIVE CULTURAL IDENTITIES}

In April 2013 the Indian film producer PVP Cinema, alongside AA Globe Services (an international logistics company responsible for Indian productions), chose Portugal as a destination for filming the telugu ${ }^{6}$ movie Balupu; two songand-dance sequences were shot in Lisbon and in Algarve. The last time a film had previously been shot in Portugal was in 1979, when Amitabh Bhachan and Neetu Singh danced in iconic areas of Lisbon (Sabse Bada Zuari, The Great Gambler). Following Spain's lead, where the shooting of the film Zindagi Na Milegi Dobara, You Won't Get This Life Again (2011) resulted in significant growth of Indian tourism, Portugal currently intends to position itself as a destination for the Indian film industry.

Resulting from a partnership between the Tourism of Portugal and the AA Globe Services the crew's visit to Portugal for ten days resulted in a private investment of 150 thousand Euros, according to a national newspaper. ${ }^{7}$ Consequently, Real Image, a leading Indian digital cinema company, decided to relocate to Portugal, where they intend to invest around 5.5 million Euros and create about 60 jobs, according to another national newspaper. ${ }^{8}$

While Portuguese scenarios feature on-screen into the biggest productions of Indian cinema, Bollywood is increasingly attracting Portuguese viewers. Although they constitute a semi-hidden minority of the population, these viewers are connoisseurs of this cinematic universe, and they have in common the factor of viewing films individually, in a domestic space (i.e., in a logic of private consumption). The next paragraphs will reflect on Bollywood cinema consumption, facing the lack of distribution of this kind of cinema in Portugal.

In the 1990s and 2000s, apart from sporadic exhibition of some Hindi films - and crossover hits such as Monsoon Wedding (Mira Nair 2001) and Water (Deepa Mehta 2005) - in Portuguese theaters, Bollywood releases were displayed only at the theater Cinestúdio 222, located in central Lisbon. Currently the place is vacant. Ricardo Oliveira Silva (2012) reported its history. The existing theater room within this commercial space opened to the public but the showing of Bollywood movies only emerged in the late 1990s, orchestrated by one of the managers, Dhimante Cundanlal. Thus, it allowed the Cinestúdio 222 to become "a venue for the dissemination of Indian culture"

6 Telugu language film industry, also known as Tollywood, is based in Hyderabad, South India.

7 See "Isto é Bollywo... perdão, Tollywood a filmar em Lisboa, Algarve e Cascais", by Joana Amaral Cardoso, Público, April 16, 2013, available at < http://www.publico.pt/culturaipsilon/jornal/isto-e-bollywo-perdao-tollywood-a-filmar-em-lisboa-algarve-e-cascais-26387152 > (last access in January 2017). 8 See "Bollywood vem filmar a Portugal", Diário de Notícias, November 23, 2013, available at < http: //www.dn.pt/artes/cinema/interior/bollywood-vem-filmar-a-portugal-3549485.html > (last access in January 2017). 
during the weekends (Silva 2012: 44). However, the acquisition, subtitling and final projection proved too costly. The public screening of Bollywood could not cope with the consumption of DVD - sold in Indian stores - and the access to satellite channels and the Internet for Indian-origin viewers. Thus, in mid-2000 the projection of Hindi films on the big screen ceased to exist, whilst leaving access to Indian cinema even more difficult for the Portuguese public in general.

Indian owners' shops are one of the access channels to Hindi cinema DVD, not only for Indian origin people but also for the remainder of the Portuguese public. ${ }^{9}$ Portuguese subtitles have poor quality, forcing the viewers to watch the films with English subtitles. A visit to a mainstream video store in the Great Lisbon area leaves one always perplexed by the section of Asian films: Indian films among Japanese ones, with the available titles oddly unknown. Only the popular crossover films or even diasporic hybrid films are available.

Thus the privileged channel for this cinema's audiences is the Internet. In this sense, both the Indian-origin people and the remaining Portuguese public are progressively moving towards the private consumption sector of Bollywood. Although it is rather difficult to access a formal Indian cinema circuit in Portugal, the Bollywood fans overcome these barriers, and many of them are experts on this genre.

The Indian-origin population in Portugal is divided into several groups (Hindus, Muslims, Sikhs, and Catholics), whose migratory history goes back to the late 1970s and early 1980s. Coming mostly from Mozambique, after establishing themselves in Portugal these people developed strong community structures, processes in which Indian cinema has played a key role. ${ }^{10}$ Although established in Portugal for more than three decades, the Portuguese Indian-origin communities still almost invisible in Portuguese society. However, they have a central role on Indian popular cinema dissemination within Portugal. We saw previously that it was Dhimante Cundanlal, who came from Mozambique and originally from India, who encouraged public exhibition of Bollywood movies in Lisbon. And despite the success of the Internet, Indian stores continue to be an important means of acquiring films. In this sense the

9 Some stores sell exclusively DVD and CD soundtracks, others are grocery stores or stationery stores that sell Indian films among other items.

10 Several authors have demonstrated the centrality of Bollywood in identity processes of diasporas (Dudrah 2002; Desai 2004; Punathambekar 2005; Bandyopadhyay 2008). The Portuguese colonial past is also linked to Indian cinema as an identity vehicle. A report from a mission to study ethnic minorities of Portuguese Overseas (Angola and Mozambique) reports the public displays of Indian cinema in the Gujarati language in Mozambique among the communities of Indian origin (Dias 1958). One of the reports' authors, Manuel Viegas Guerreiro, first assistant of the Mission, criticizes this cinema as subversive, exalting the superiority of India over the West and, as such, a threat to the Portuguese colonial enterprise. I thank João de Pina Cabral for making me aware of the existence of this document. 
Indian presence in Portugal has influenced, although not directly, Bollywood mainstream consumption. ${ }^{11}$

\section{THE AUDIENCE: DYNAMICS OF PRIVATE CONSUMPTION}

We already noted that Bollywood consumption by Portuguese audiences has particularities distinct from other Indian cinema audiences outside India. Unlike other countries, where the Bollywood craze is displayed publicly, in Portugal its consumption is eminently private. Compared to the British context analyzed by David (2010), for example, the Portuguese audience of Hindi cinema has no access to public exhibition of the films. We will analyze these factors using the notions of private consumption and wellbeing.

In addition to the Indian-origin population, which mostly has direct access to Bollywood either through the DVD, or by cable television (i.e., television channels such as ZTV and B4U), the popularity of Bollywood also extends to groups of immigrants from former Portuguese colonies in Africa such as Mozambique or Angola, who show preference for this type of films as they were used to watching them in Africa, where Indian communities were well-established.

The group covered by the scope of this research is a group of people who have no connection either to India (only two of my interlocutors have ever travelled to India) or to the diasporic communities in Portugal. The audience of this case study is a group of 40 people aged between 19 and 46, mostly in their 30s. Composed of a majority of women, this group includes only 6 male members. The socio-cultural level of these individuals is medium-high. Although centered in the city of Lisbon, this study extended to other areas of Portugal: Porto, Leiria and Madeira.

After the participants were identified in this investigation, I conducted informal interviews to learn my interlocutors' film preferences, and to understand, in the foreground, the reasons that led them to obtain a deeper knowledge of this kind of cinema. From this I could analyze the social and cultural impacts of Hindi cinema in their lives. The methodological tools of anthropology allowed me to spend time with people to watch cinema, to talk to them about movies, and finally to articulate this information within the audience's social and cultural context: that is, how this audience responds to a certain movie, and how this reflects socially and culturally. In this sense, film should be considered as an integral part of society and not a mere reflection of it:

11 The current visibility of the Indian presence in Portugal is due largely to the arts, particularly dance; see the case of the work developed by kathak dancer Lajja Sambhavnath (from the Hindu Community of Portugal) together with Portuguese artists, such as the Bharatanatyam dancer Tarikavalli or the sitar player Paulo Sousa. 
"Cinema is embedded in society just as cultural values and social knowledge is embedded in the cinema" (Gray 2010: 133). Therefore, analyzing the consumption of cinema allows us to understand the social uses of culture.

According to Bollywood movie sellers in the city of Lisbon, Caminho das Índias (The Pathway to India), the Brazilian soap opera produced by Globo television network that had everyone searching for tinkling jewelry and colorful robes in 2009, and also the eight Oscars awarded to Slumdog Millionaire, the film by Danny Boyle and Loveleen Tandan from 2008, with a soundtrack which featured Jai Ho, A.R. Rahman, and the Pussycat Dolls, both have infused in some Portuguese people the desire to watch Indian movies. This is the angle that Indian vendors privilege in their sales strategies (via Internet websites, blogs, etc.). In contrast, my interlocutors refer to personal and independent events that sparked their interest in Indian cinema.

In most cases it is a personal quest, inspired by contact with soundtracks from Bollywood movies, the personal interest in an actor or actress, or documentaries related to India. It should also be noted that some people mention the influence of their parents' generation, which relates to the 1970s' exhibitions of Indian films in the theaters of the main Portuguese cities, such as Lisbon and Porto. Some of the interlocutors report having watched with their parents an Indian film that resonated with them and subsequently resulted in a deeper search for Indian popular cinema. In summary, the collected data suggest that participants' interest in Bollywood derives from personal and private searches, in addition to the influence of the global cultural flows of exotic consumption of India.

After analyzing the impetus for the consumption of Bollywood, we need to examine the key elements that Hindi cinema fans highlighted about their favorite films. Firstly, they stressed the visual appeal of Bollywood, particularly associated with the song and dance sequences, composed of elaborate choreographies and lush clothes, and always featuring stunning scenery. In this context, Bollywood aesthetics and kitsch elements exert the initial attraction, as illustrated by the following words of a 31 -year-old female interlocutor: “... it all started in 2001, when a friend lent me a CD with songs from Indian films of the 70s and 80s. At the time I found it very kitsch and fun."

The wellbeing these films generate is corroborated by the large majority of Bollywood fans, and can be thought as the central appeal of this consumption. A 35-year-old male viewer says of Bollywood movies: "It is good for [one's] health and [those] who watch it feel good. Besides, it is completely addicting!" The focus on the wellbeing emanating from these films is common among all interlocutors. In some cases, watching Bollywood movies becomes an addictive hobby. A 46-year-old male interlocutor states: 
"I spend a lot of time with my Indian films. When I get home I eat something and I go to the Internet to check for more Indian films and then entertain [myself by adding] subtitles. Everyday. Some days I don't even watch television [...] I now have about 500 movies on DVD and all subtitled in Portuguese. Sometimes I need a couple of weeks to get a movie. For example, when the subtitles are in English or Spanish, then I have to translate it and watch the film in stop-start to make the subtitles."

Besides being a personal addiction, Bollywood consumption is essentially private. The participant quoted above refers to this trend: "When I watch a Hindi movie I like doing it alone because I like living [in the world of] the movie and I'm more comfortable." If, on the one hand, the question of personal and private pleasure is very relevant here, we should add that this private consumption can also be affected by the stigma that Bollywood carries for many Portuguese. This is indicated by a 38 -year-old female interlocutor:

"Only my mom and I like Hindi movies. I cannot convince my sisters. I never [could]. My friends always mocked me because I like Indian films, since I [first] began to [watch them]. Now only my sisters still know that I watch and love Bollywood. I do not share this passion with anyone, [as they would] continue [to] mock me!"

Bollywood cinema works as an alternative to Western mainstream cinema. The fact that it does not contain "sex scenes" or "bad language" is mentioned by several participants in this research as a more palatable alternative to Hollywood cinema. Considered "good for all ages" [female participant, 38 years old] they have a moral concern, as the actors "show an intensity of feelings without resorting to scenes of intimate physical involvement" [female participant, 31 years old].

Overall, despite a subsequent interest in India due to the attraction by the Hindi cinema, the majority of these Bollywood fans are not enthusiast consumers of other commodities of Indian origin. Only two interlocutors in this study admitted a fascination with "all that is Indian." The author of this sentence, a 3 l-year-old female, continues: "I love Indian films and I am sorry that there are no more places [to buy them from]. I love Indian music. At the moment, I have about $50 \mathrm{CD}$ that I hear almost daily. They are almost movie soundtracks. I also love Indian classical dance." This Bollywood fan proceeds to list Indian clothing, mythology, and food as other passions. Likewise, another interlocutor, a 33-year-old female, claims to like a bit of everything that is Indian. Besides cinema, clothing, food and dance, she adds: "I practice yoga and vedic lessons. I also love henna tattoos that I practice on myself... 
In addition, I study Hindi [language]. Maybe one day I will be able to watch a movie without subtitles!"

Only these two testimonies suggest an overall fascination with India, evident in the consumption practices of both these interlocutors, as well as in their daily lives and lifestyles. The remaining study participants direct their interests primarily to the cinema. For these people, India as a cultural reference does not dominate their consumption practices; neither does it occupy their daily lives. Here's an example of a 31 -year-old female:

“... I used to listen to soundtracks [from Hindi films] before I started to watch them. That's why Indian music is very present in my life, as well as the cuisine and decor. As for the latter two, they did not arise because of the films, I think. [...] As for clothing, I confess I do not use anything traditionally Indian, [it] does not [fit in with] my personal style. And the same [goes for] Bollywood dance. I have no interest. [...] The same applies to yoga. I have no interest or curiosity [...] The [Bollywood] films allowed me to get to know a little about the religious and spiritual side of India but that's it. I like to know and learn but not to the point of adopting some kind of religious or philosophical practice."

As we can see from the excerpts reproduced above, this scope of analysis is heterogeneous. The fact that the majority of individuals do not know each other contributes to this diversity. I'll try, however, to summarize the impact of India in the social and cultural practices of these individuals. Some stereotypes about India were found in the discourses of these participants, particularly those of a spiritual and tolerant India. Fantasy is one of the elements most appreciated by Bollywood fans, and in general they are aware that Bollywood is not a reproduction of the real India. Thus it is not the real India they want to consume, but an imagined, exotic and Orientalist India. They seek fantasy, above all else: "The Indian popular cinema is very fanciful and while it may seem unrealistic or old fashioned, I believe the filmmakers strive to make beautiful, more than deep, works" [female participant, 31 years old]. This fantasy, coupled with pleasure, results in wellbeing, as summed up in the following sentence of a male 35-year-old spectator: "Quite frankly, I find it impossible not to like those two-and-a-half-hour - at least - movies that can make us dream, laugh, cry, dance and sing like no Hollywood movie could!"

India has always seduced the European imagination. Portuguese held an early fascination over this country, associated with the Portuguese Discoveries and the colonial process. ${ }^{12}$ The old Orientalism, in which representations of

12 For a critical analysis of the symbolic and political construction of Portuguese colonial empire, see Perez (2006). 
otherness were grounded, seems now to arise in other areas reissued as a New Orientalism in a context of globalization and new forms of identity within the cosmopolitan Portuguese society. India is a central reference in contemporary cosmopolitan European fashion. The consumption of Indian cultural references has become common in Portuguese society, as in other European contexts, which is expressed in the growing demand for products such as film, literature, cuisine, and clothing. The public finds these cultural products increasingly available in a market that some authors refer to as Indo-chic (Maira 2007). Focusing on the phenomenon of consumption of Indian popular cinema and other associated elements, this approach seeks to analyze the social uses of culture and the creative process of these cultural borrowings.

By the same token, we could say a priori that for most Portuguese viewers, Indian popular cinema represents, to some extent, India itself, even with images and cultural constructions often remade as more essentialized and exotic. This paper will discuss how these images are perceived by my interlocutors, and whether or not this phenomenon can be framed within a process of New Orientalist fascination.

This study's empirical work deserves to be analyzed in detail to evidence the complexity of this issue. Although for some India has a very relevant role in the various dimensions of their everyday lives, the majority of interlocutors show a particular fascination for Indian popular cinema. Despite the obvious interest associated with India, Bollywood works for these audiences as a vehicle of wellbeing. The idea of obtaining pleasure from these films is common to all members of this audience. This results not only from the typical Bollywood themes but also from the spectacle provided particularly by song and dance sequences. Considering the music as "the central axis along which desire and identification are calibrated" (Gopal and Moorti 2008: 5) and the dance as a "temporary permission" (Prasad 1998), these are core elements in the creation of feelings of pleasure.

Consumption is a means of constructing identities and generating communication of social and cultural affiliations. Thus, one would expect the consumption of Bollywood to develop in some way through groups of individuals who share this taste. Providing meanings to the goods consumed allows us to think of them as a means of communication between people (Douglas and Isherwood 1996 [1979]). However, the presented data suggest that, on the contrary, Bollywood proved to be an eminently private - if not hidden - consumption.

Two factors contribute to this isolation. The first was the fact that Bollywood in Portugal is an individual consumption, which does not extend to all levels of individuals' lives, and which does not include them in specific social or cultural movements. Additionally, this audience is confronted with stereotypes about Bollywood cinema in their social, cultural and family surroundings - in general, Indian cinema is seen as kitsch and of poor quality. These factors 
lead to a private consumption or pleasure, where desire and fantasy play a decisive role.

Instead of uniting people with common tastes, this phenomenon proved rather to be a practice that gives access to individual viewing and solitary pleasure. Accordingly, the films can be thought of as a form of "exutory." The term, of medical origin, is used by João de Pina Cabral (2003a, 2003b) to describe a mechanism allowing the release or eradication of a need or desire (Cabral 2003a: 75). Likewise, Hindi films work for their audiences as a way to release their fantasies and desires into a personal and secret pleasure channel.

However, hidden Bollywood consumption does not inhibit this audience from monitoring the glamorous universe of Bollywood: there are fans of actors such as Shahrukh Khan or Aamir Khan fans, for instance (Shahrukh Khan is an example of global popularity, with his body being an object of global consumption, the consumption hero). But what could potentially be a shared worship, creating a community of fans, is instead a lifestyle overshadowed by the fear of ridicule. Only one of my interlocutors, a 21 -year-old Bollywood fan, also practiced Bollywood dance, nourishing her wish to take part in this dream world by investing in a professional career as a Bollywood dancer.

Cinema gives access to a world of fantasy that conveys pleasure and provides wellbeing. The act of buying, according to Miller (1998) should be perceived as a way of disclosing the processes that create universes of affective and personal development. The consumption of Bollywood fits within this logic, in the sense that it offers to its consumers a universe that generates pleasure, and which results in personal wellbeing.

This fantasy is often associated with an exotic and traditional India. The fascination of India varies from person to person, but in general, they all show interest in the country of origin of these films and their cultural heritage. The analysis of the participants' discourse reveals some stereotypes about India, as well as some Orientalist notions of India and its inhabitants, related to religion and spirituality. They often refer to Indians as a very spiritual and tolerant people, and to their cultural traditions as ancient. However, this interest in India and its most popular cinema should not be reduced to a form of old Orientalism, but rather be thought of as a form of contemporary access to ethnic difference which results from the global circulation of Asian popular media through processes of remediation, i.e. a New Orientalism. To state that these individuals are in search of cultural alternatives to Hollywood-dominated Western cinema is not an adequate explanation as to why they resort to these media forms of recreation. As this research has allowed us to perceive, though some interests related to India are part of the social and cultural activities of these people - such as yoga or Indian cuisine -, such interests do not dominate their personalities or their personal relationships. Likewise, they are not visible in their clothing styles nor in other elements of body encoding. 
To focus on the relationship between (Orientalist) desire, pleasure and fantasy is also useful for this discussion. Bollywood cinema is characterized by musical sequences that interrupt the narrative, making actors and also the audience travel for fantastic displacement. The cinema of interruptions (Gopalan 2002) allows the blending of seemingly contradictory musical moments whose set is actually essential to the film's narrative elements. The musical interruptions are the moments most appreciated by the Portuguese audiences, integrating Bollywood aesthetics. In the same way that these social fantasy narratives allow Indian-origin audiences to re-imagine their everyday lives (Dickey 1993), so too they allow the Portuguese fans to access a fantasy world, as an alternative of escapist pleasure.

If we consider that the most recent song-and-dance sequences depict cosmopolitan contexts and are full of Western influences - often filmed outside India, using non-Indian dancers - we can easily realize that what attracts these audiences to Bollywood films are not only the exotic elements and traditional stereotypes of India, but also the prospect of an alternative form of entertainment, which generates pleasure through fanciful escape, working in the background as "exutory."

Thus, consumption of Bollywood does not aim at membership of a particular social group, nor does it greatly influence lifestyles. It is for these reasons that Novak's approach is relevant, that is, to analyze this consumption as a practice of cultural appropriation that generates "new cosmopolitan subjects" (Novak 2010: 40). Novak's approach departs from the analysis of remediation processes and how these are creative acts "[that feed] circulating media into new expressions and performances" (Novak 2010: 42). Although particularly useful for analyzing the practice of Bollywood dance, which will be discussed later, this approach helps us to understand the consumption of Bollywood film not as a pure form of Orientalism that offers an escape to another culture, but rather as a phenomenon of cultural borrowing that challenges the idea of singular politics of cultural identity (Novak 2010: 42). The new cosmopolitan subjects are those who appropriate the "other" media without feeling the need to emerge cloaked in their cultural references, and without having to alienate from their own cultural representations. The concept of cosmopolitanism, however, always implies the existence of - economic and social - capital and therefore should not be used simplistically to refer to the capacity of "openness" to the new contemporary cultural geographies.

The act of consuming contributes directly to the construction of both individual and group identities, if we consider that culture consists of a system of production and consumption of signs in which individual consumption is a social activity, consumers being involved in a system of exchange and coded values production (Baudrillard 1988). Processes of cultural appropriation and their consequent decontextualization reveal that the construction of "other" 
cultural references is often based on stereotypes associated with their societies of origin. The passion for Bollywood is integrated in the urban culture of ethnic consumption, together with a general interest in India. The idea of remediation, however, suggests the processes of cultural circulation and globalization as generators of people able to make cultural appropriations in accordance with their personal goals, thereby creating mediated cultural references. In this context, the media have a key role. The idea of remediation will be explored further below. For now, it is important to recognize that Portuguese Bollywood audiences do not seek this cinema merely as a pure form of consuming India itself, but rather as an escape, generator of wellbeing and pleasure, whose cultural representations are clearly distinct from theirs, but incorporated in a mediated form.

\section{"I DO NOT MAKE IT A LIFESTYLE":}

BOLLYWOOD DANCE AND URBAN COSMOPOLITAN IDENTITIES

In 2002, the journalist Ruth la Ferla published in the New York Times a text called "Kitsch with a niche: Bollywood chic finds a home," where she described the phenomenon of the arrival of Bollywood in New York and the influence of its aesthetics in several areas beyond the films. ${ }^{13}$ Fashion, music, food travel, and cosmetics were strongly influenced by "Bollywood chic" and entered the mainstream in Europe also, and Portugal was no exception. Portuguese consumption of Bollywood does not fit in a context in which Bollywood style is crossover. Generally, beyond cinema, these audiences did not extend the Bollywood spirit to other social and cultural spheres of their lives, beyond the interest in India that films may have originated.

While previous works produced on the practice of Bollywood dance pore over the diaspora and identity issues of the descendants of South Asian youths, this article seeks to observe Bollywood dance in Portugal through its non-Indian-origin practitioners. This empirical collection aims to shed some light on this "hybrid and evolving art form" (Gopal and Moorti 2008: 46) and on its impacts on new cosmopolitan subjects as alternative cultural and artistic ways.

This case study focuses on the practice of Bollywood dance in the Greater Lisbon area. This research concentrates on two Bollywood dance classes from different schools, and on the interconnected work of a dance company. All are guided by a professional dancer in traditional Indian dance. The study was conducted at the school Dance Factory Studios (Lisbon), and in the sports club Complexo Desportivo de Alcabideche (Cascais). At both locations classes are taught by teacher and choreographer Diana Rego, who has training in

13 See < http://www.nytimes.com/2002/05/05/style/kitsch-with-a-niche-bollywood-chic-finds-a-ho me.html > (last access in January 2017). 
classical ballet and ethnic dance. ${ }^{14}$ Today she's a dancer and choreographer of the Anaidcram group of world music and dance, dancer of the Gadjé gypsy music and dance group, dancer of the Kelana Asian dance group, and in 2010 she founded her own dance company, Companhia de Dança Diana Rego. In 2013 the company increased the public visibility of its work, with particular emphasis on the Bollywood performances, through successive participation in TV shows on several different channels. This reflects the growing interest in Bollywood within the Portuguese society. ${ }^{15}$ The company often presents shows that combine classical, traditional and Bollywood performances, as well as performances inspired by Southeast Asian styles.

Bollywood dance classes are conducted weekly as a form of recreation and physical activity, but some of the students also participate in stage performances choreographed by Diana Rego. These dance classes were the means by which I was able to meet the participants, all women, between 16 and 40 years old. I had conversations with them before and after classes, and besides these moments I conducted informal interviews with them. The process of approaching these participants required my own participation in these classes, as it was the only way to have access to the practitioners of this type of dance.

Classes begin with warm-up exercises, mostly inspired by yoga exercises. The students initially practice various movements of hip rotations and wrist whirls and then begin the steps of the choreography. Choreography is arranged to songs from Hindi films and is then practiced consistently. This choreography, however, in no way resembles the original; it is a fully new creation of the teacher and choreographer, solely with the music in mind. In this sense, the narrative of the film and the original choreography have no influence on the new routine.

Although inspired by the movies, Bollywood dance often consists not only of the reproduction but also of the transformation of song and dance sequences from the films. As we have seen, a key feature of these dance sequences is that they can be removed from the structure of the film. Indeed, the migration of Hindi film dance to the stage often involves the transformation and adaptation of movements from the original narrative dance. Originally designed for this purpose, these sequences can thus be appreciated separately from the

14 Diana Rego trained with various ethnic dance masters: Prisca Diedrish from Germany, Myriam Szabo from France, N'ganou Annie from Cameron, and Shokry from Egypt, among others. Her training spans capoeira, African dance, new circus, contemporary dance and yoga. She also made several study trips to Spain, Greece, Turkey, Israel, Africa, China, Indonesia and India, having deepened her research particularly to the study of Indian classical dance, Bollywood and belly dance (Raqs Sharqi). 15 In the year it was created, 2010, the company participated in the Portuguese version of the show So You Think You Can Dance?, where Diana Rego was invited to choreograph a Bollywood performance. Since then, the company has been invited to perform at various TV shows. 
films, giving meaning to the expression masala, normally used to mean a mix of contents, from which song and dance sequences can be separated. However, despite their ability to detach, these sequences have an "extra-narrative role of linking a film to Indian tradition" (Dudrah 2006: 48), and enrich the movie through their use of metaphor.

Focusing on practitioners belonging to the South Asian diaspora, the literature on Bollywood dance leans heavily on notions of nostalgia related to cultural belonging within India. The feelings of desire and fantasy are linked to a deep relationship with the world of Hindi cinema. According to David (2010: 217), practicing Bollywood dance is fueled by the act of film-watching itself. Likewise, Shresthova stated that Bollywood dance "allows audiences to not only watch, but also experience firsthand, their favorite song-and-dance sequences" (Shresthova 2011 : 3). The spectrum of analysis discussed here has different features and also a distinct relationship with the world of Bollywood cinema.

The discourses of Bollywood dance practitioners - all female - will shed light on this. As a 27-year-old amateur dancer says:

"I arrived in Bollywood [dance] through belly dance. The teacher was the same and I decided to try. These dances brought back my femininity. I watched some Indian films but I do not watch them very often. I prefer to watch only the choreography. I like Indian culture but I do not do it [as] a lifestyle."

Another amateur practitioner, a 15-year-old girl, says:

"This dance is very funny, relaxed and more flexible than the classical practice (contemporary, traditional Indian). It's liberating and gives you wellbeing. Occasionally I watch Indian films but I don't retain the titles or actors' names, it is more out of curiosity..."

These two excerpts reflect the majority of the students' opinions. Their relationship with Indian cinema is very superficial and in many cases the first contact came after contact with Bollywood dance. However, this phenomenon presents an opposite claim to that presented by the students in David's study. The practice of this dance is not fueled by Bollywood film, but rather fuels the interest in the latter. The amateur dancers came to Bollywood dance through different paths and their contact with Indian traditional references starts from there. Some interests related to India, such as food, are referred to by the students but none have adopted a particular lifestyle connected to India. Beneath is another excerpt from an interview with a member of Diana Rego's dance company: 
"I started to practice traditional Odissi dance and Bollywood five years ago, and one year ago I joined Diana Rego's dance company. I have a strong connection with India but cannot explain why. Especially because that does not dominate my life. I find [ridiculous the] people that convert completely and use a bindi on the forehead."

It is interesting to note the various representations that can be made around the bindi. ${ }^{16}$ If to the young woman interviewed the use of bindi is associated with the excessive appropriation of Indian cultural elements, Maira notes, supported by Misir (1996), that the fetishization of bindi in the United States was preceded by the negative connotation of the Indian immigrant's stereotypes. In the USA of the 80's they were seen as "cultural unassimilable 'dothead's" (Maira 2007: 238).

For these practitioners Bollywood dance is integrated in an urban culture, similarly to what David finds regarding not only those of Asian origin, but also non-Asian participants for whom this urban culture combines an "interest in multiculturalism in the host community, and perhaps also links to issues of the "exotic other'" (David 2010: 217). In fact, this idea proposed by David can be applied to the case under study. For Portuguese practitioners, Bollywood dance gives them access to an alternative and exotic cultural universe that they then integrate with their own urban and cosmopolitan culture, for which multiple influences compete without necessarily imposing on Indian culture. The complexity and flexibility of this practice also allows greater freedom with regard to creativity and re-interpretation. In the passage from the screen to live performances, this phenomenon leads to "competing definitions of Bollywood dance, both as set and fluid; codified and changing; created and interpreted" (Shresthova 201 1: 9).

It is time to return now to Novak's approach that I used as a fundamental method: the process of remediation. Using the concept introduced by Bolter and Grusin (1996), according to which the remediation process allows "[the transferring of] content from one format to another, making media new, making new media," Novak adds that this concept allows one to reconsider the role of the subject in the study of movement and cultural globalization, through the practices of cultural appropriation, which leads to the creation of contemporary cosmopolitan subjects (Novak 2010: 41).

The potential for separation of song and dance sequences from the films to which they belong makes these sequences particularly easy to be remediated. Novak demonstrates how the song and dance sequence "Jaan Pehechan Ho" from the film Gumnan (1965) circulated in non-diasporic North American 
media. This dynamic clearly illustrates the remediation process. With regard to Bollywood, this phenomenon applies to the circulation of film clips - not the full movie - and its appropriation as creative acts, "which feeds circulating media into new expressions and performances" (Novak 2010: 42), thereby composing alternative modernities (Gaonkar 2001), without these necessarily implying an immersion in "other" cultures. It is in this context that the practice of Bollywood dance can be discussed.

The ethnographic case examined in this study corroborates this idea. As we have seen, contrary to what is shown in the UK by Ann David (2010), Bollywood dance classes in Portugal have few students of Indian origin. In Portugal, Indian origin youth meet informally to rehearse performances that will then be displayed in cultural festivals, at weddings, or in activities taking place within their communities; these public performances consist of mimicking the choreography of the movies in from which the sequences presented originated. In contrast, the Bollywood dance classes that were the target of my ethnographic observation transpired to be much more creative from the performative point of view. Both classes and public performances include choreography to the music of famous sequences of Hindi films, recreated in a form separate from both the film and the original choreography. The teacher and choreographer creates a new structure, intensifying the use of classical dance postures such as mudras. ${ }^{17}$

Here's an excerpt from my field journal:

"During one of the academy's classes that I attended, the dancers were rehearsing for a private party of Portuguese public figures. In the end the teacher invited the audience to comment. I mentioned that I found very interesting the adaptation of 'Dola Re Dola', originally from the movie Devdas, a Rajasthani martial choreography in which two women faced each other with knives. One of the dancers was surprised by my comment and said that she had no idea that this performance was linked to a narrative in which two women confronted each other over the same man's love. The choreographer answered: 'Oh, yes, that was in the movie...'" [field journal, December 12, 2012]

This example confirms the distinction between the original media, in this case the Hindi film Devdas (2002), its narrative and performances, and the remediated media, resulting from an appropriation of a film's excerpt and its use as inspiration for a new performance. These creative acts result from cultural borrowing processes driven by global media, demonstrating why transnational 
consumption of Bollywood should not be thought of as a simple Orientalist act, i.e., that of completely "consuming India." These dynamics may rather consist of a cultural alternative in which cultural exchange and negotiation, along with artistic creativity, and some Orientalist constructions are present.

Another factor helps to qualify this phenomenon as an act of remediation. Unlike David's practitioners of Bollywood dance, my interlocutors did not first encounter this practice through Hindi films. In fact, among Bollywood film fans analyzed in the previous ethnographic case, only one practiced Bollywood dance. The interviews with Bollywood dance practitioners revealed that most of them discovered Indian cinema only after their contact with these classes. In a more or less enthusiastic way, Bollywood movies work more as an inspiration to dance than as a frequent entertainment form.

Hampering Bollywood dance definitions for being "both set and fluid; codified and changing; created and interpreted" (Shresthova 2011: 9), this practice allows the creative appropriation of these dances, characterized in this case by the intensification of movements and postures from Indian classical dances, allowing choreographic freedom according to both the dancers' and the public's tastes. In addition to the aesthetic character, this intensification of traditional elements from Indian classical dances, such as mudras, reveals a concern in exacerbating a culturally distant form of dance.

Therefore, following this idea, rather than focusing on the differences that a performance suffers in the translation from film to stage or to classes, it is important to understand how cultural reappropriation of these materials through creative processes leads to Gaonkar's "alternative modernities" (Gaonkar 2001) and the construction of social relations through mediated references. The complexity of the analyzed phenomenon prevents us from reaching simple conclusions. Global and multiple identities of these individuals combine various cultural elements without implying an exclusive attraction to India, but evidencing a New-Orientalist influence.

This research intended to show that, contrary to findings from the previous case study, practitioners of Bollywood dance in Portugal are not concerned with a deep knowledge of Bollywood cinema. Despite occasional movie watching, they do not know the names of movies or actors, focusing more on the choreographies. While exhibiting some interest in India's cultural references and differences, they do not exhibit the degree of fascination on Bollywood cinema as the first group.

Although different, both cases illustrated how the concept of remediation is useful to understand the appropriation of Bollywood song and dance sequences, by Bollywood audiences of Hindi popular cinema as well as by Bollywood dancers in Portugal: it does not necessarily imply a detachment from an authentic culture, but neither does it end in a process of purely exotic essentialization (Novak 2010: 63). However, the idea of cosmopolitanism that 
complements Novak's argument is problematic. Cosmopolitanism should not be simplistically understood as the capacity for openness to "other" cultural references. Cosmopolitanism implicitly implies a relationship of power, in which the "other" is always in a disadvantage position.

Maira's approach on the rave culture, despite suggesting a classic performance of Orientalism by the appropriation of exotic elements, such as the Hindu or Buddhist symbols, and India - particularly Goa - seen as the genesis of electronic music featuring these parties, does not necessarily mean an Orientalist consumption (Maira 2003: 15). By analyzing the speeches of the participants in this kind of events the author chooses to frame them in a perspective of "discourse of universalist humanism" (2003: 19), as an alternative to the notion of cosmopolitanism.

The conflicting views of young female Bollywood practitioners show on the one hand the concern to demonstrate their ability of openness to "others" and, on the other, to demarcate from those who emerge completely in "other" cultural references. Similarly, Maira's young ravers negotiate their cultural anxieties through narratives about "other" cultural geographies, which allow us to understand how Orientalism and cosmopolitanism can go hand in hand (Maira 2003: 21).

The contradictory discourses of Portuguese interlocutors also reveal Orientalist representations associated with femininity, the potential of this practice to rescue the lost femininity found through the East as the feminized and eroticized "other" (Saïd 1995 [1978]: 103-104). The presence of an Orientalist imagery associated with belly dancers is revealed by the fact that several Bollywood dance students simultaneously practice belly dancing.

Summarizing, Bollywood consumption in Portugal features an orientalist hybridity that is present in the "transnational culture performances" through "mediated representations of the Orient as the erotic exotic feminine Others" (McGee 2012: 233).

\section{CONCLUDING REMARKS}

The global fascination with Asian cinema entails a concern for aesthetics, forms and narratives it provides, which seem to have revitalized Hollywood - see for instance Chicago (2002), Moulin Rouge! (2001) or hybrid films like Monsoon Wedding, which increased the visibility of South Asians in Western popular imagination. According to Desai (2006), these influences made Bollywood movies and music "family exotic" for non-Indian audiences, keeping a clear separation of Orientalist conceptions and South Asia's complex reality:

"It is not clear, however, that Eurocentric viewers know quite what to expect from these passing allusions to Bollywood in dominant media; armed 
with their long-standing Orientalism and their contemporary benevolent compassion, many may be quite surprised by their experiences at the theaters. With many Indian films thematically battling over the binary of tradition and modernity, mini-skirted and designer-clad characters, and palatial homes with their colonial and Orientalist images of dust and poverty or chaos and terror. Expecting images of Indiana Jones, the British Raj, or the Kama Sutra, these viewers may not welcome more recent films such as the four-hour nationalist $\mathrm{LoC}$ (Line of Control), or the romantic comedy set in New York, Kal Ho Naa Ho, with homophobic comic relief" (Desai 2006: 121).

On the other hand, the success of Bollywood epics such as Lagaan (2001), and hybrid films such as Monsoon Wedding (2001) and Bend it Like Beckham (2002), suggests that Western audiences may be interested in films that confirm their own nostalgia for traditional imagery, where cultural differences are valued in a Eurocentric frame.

With the liberalization and reintegration into the global economy from the years 1991-92, India became part of "the global culture industry as a 'producer/exporter' of cultural commodities - or the raw material for what became cultural commodities in the West" (Toor 2000: 1). This process triggered a comprehensive exposure of India and its people's representations, with vestiges of the past in the New Orientalism and in the New Indo-chic (Toor 2000: 1).

We saw, through the above analyzed empirical data, how Bollywood cinema consumption in Portugal has certain particularities not found in other nonAsian contexts. This relates to small-scale consumption, hampered by the lack of public watching. The stereotypes associated with this kind of cinema, which are very rooted in Portuguese society, have also contributed to individual and private consumption, where fantasy and pleasure come together as forms of wellbeing.

Consumption of Bollywood as remediated cultural dynamics originates a universe of alternative cultural practices by new social subjects who through cultural borrowings accede to "pleasure and desire that are interwoven with identification and reproduction - all elements embedded in both the viewing of the films and the reproduction in the dancing bodies" (David 2010: 223).

India has become a commodity in the alterity industry (Huggan 1998: 246) directed largely to the West. Example of this phenomenon was the proliferation of contemporary postcolonial writing and its transformation into a "cultural commodification" (Wachinger 2003: 71). These phenomena are products of the globalization of Western capitalist consumer culture that propelled the massification of exotic merchandise (Huggan 1998: 254). 
In the case of Bollywood dance in Portugal, the explosive growth of this practice is developed through New Orientalist rhetoric, as shown by some examples of Bollywood dance classes advertising slogans: "Come to know the way and the flavors of India through dance!" (Bollywood dance workshop, Brahma House, Porto); or "Come and meet the exotic flavors of India with a lot of rhythm and color!” (open class by Kajal Ratanji, Dance4you, Matosinhos).

The case of Bollywood dance, however, demonstrated how this practice is not an exclusive universe of Orientalist fascination but rather entails identity construction processes of various cultural appropriations in which Orientalism is also present. This study's interlocutors have clearly defined themselves as people with some interest in Indian culture (without that implying a cultural immersion, i.e., without making a lifestyle of it), as well as in other cultural references, which makes them cosmopolitan citizens, that is, people with the capacity - the social and economic capital - to accumulate different cultural references in their identity construction processes.

Finally, both cases illustrated how the cultural appropriation of Bollywood can originate alternative cultural forms through which multiple cultural references intersect without one undoing the other. The exotic elements present in the analyzed cultural practices should not be reduced to a purist form of Orientalism in which individuals yearn to escape reality for a distant culture. Rather, it should be understood as "mediated representations of the Orient," as McGee (2012) defines the "Orientalist hybridity" of the Pussycat Dolls video "Buttons," constitutive of the New Orientalism. As Novak's research suggests, these processes imply "multidirectional overflows of media resources shaped by cultural differences, globalist desires, and cross-cutting aesthetic affinities" (2010: 63).

However, cosmopolitanism cannot be thought of only as "the willingness to engage with the other" (Hannerz 1996: 103). Analyses of Western consumer habits on "exotic merchandise" allow us to understand that this phenomenon implies the existence of a "cosmopolitan capital," often intertwined with social distinction strategies (see Bennett et al. 2009; Weenink 2008). Skey's study (2013) shows how cosmopolitanism should be theorized according to its variability, frequency and inconsistency instead of being thought of as a characteristic of certain individuals or social groups. In addition, voluntary cosmopolitanism - since there are other forms of cosmopolitanism that may be involuntary, as in the case of immigrants - always implies the existence of capital and a privileged situation towards the "other," usually excluded from this process:

"Lumping together such varied activities under the banner of "cosmopolitanism' risks closing down our understanding of these complex social processes where it should begin. Put bluntly, they involve different 
processes of imagination and identification, are shaped by particular historical and social trajectories, and engage (and exclude) notable 'others'" (Skey 2013: 250).

We have seen, with Dudrah (2006), how movies make room for wishes and fantasy and how the song and dance sequences are what Prasad called "permissiveness temporary sites" (1998). The empirical data presented here support these ideas. These cultural forms lead to the consumption of fantasy, to pleasure and wellbeing. They are cultural alternatives constructed through the appropriation of Bollywood, together with New Orientalist rhetoric, and with the ambiguous notion of cosmopolitanism.

The Orient as "exhibition," to use Mitchell's idea (1989) is displayed in contemporary global commodification of Indian cultural references and practices, while Indian-origin communities established in the Portuguese society remain invisible for over 30 years. The perceptions of these groups on such consumption processes, as well as their role in its dynamics, certainly deserve further investigation, which will be a relevant future contribution to understanding this phenomenon. We perceived how exotic representations of India remain in the analyzed cultural practices and how they coexist with unknown and stereotyped Indian origin communies' cultural practices in Portugal. These continue escaping the selection of what is "Asian cool" in Lisbon and in major European capitals. Thus, the invisibility of India and Indian-origin people in the Portuguese public sphere reveals that cultural appropriations are made within a framework where New Orientalism continues to account for what is and what is not likely to be consumed. 


\section{REFERENCES}

ACHARYA, S., 2004, Bollywood and Globalization. San Francisco, CA, San Francisco State University.

BANDYOPADHYAY, Ranjan, 2008, "Nostalgia, identity and tourism: Bollywood in the Indian diaspora", Journal of Tourism and Cultural Change, 6 (2): 117-133.

BAUDRILlARD, 1988, “The system of objects", in Mark Poster (ed.), Selected Writings. Stanford, Stanford University Press, 10-28.

BEDOWS, Emma, 2008, "The methodological issues associated with Internet-based research", International Journal of Emerging Technologies and Society, 6 (2): 124$-139$.

BENNETT, Tony, et al., 2009, Culture, Class, Distinction. London, Routledge.

BHATTACHARYA, Nandini, 2004, “A 'basement' cinephilia: Indian Diaspora women watch Bollywood", South Asian Popular Culture, 2 (2): 161-183.

BOHEMER, Elleke, 1998, "Questions of neo-Orientalism”, Interventions, 1 (1): 18-21.

BOLTER, Jay David, and Richard GRUSIN, 1996, Remediation: Understanding New Media. Cambridge, MA, The MIT Press.

CABrAl, João de Pina, 2003a, O Homem na Família: Cinco Ensaios de Antropologia. Lisbon, Imprensa de Ciências Sociais.

CABRAL, João de Pina, 2003b, “A ficção como exutório”, Revista de Comunicação e Linguagens, 32: 53-60.

CIECKO, Ann, 2001, "Superhit hunk heroes for sale: globalization and Bollywood's gender politics", Asian Journal of Communication, 11 (2): 121-143.

DATTA, Pulkit, 2008, Bollywoodizing Diasporas: Reconnecting to the NRI through Popular Hindi Cinema. Oxford, OH, Miami University, B.A. dissertation.

DAVID, Ann, 2010 "Dancing the diasporic dream? Embodied desires and the changing audiences for Bollywood film dance", Participations, 7 (2): 215-235.

DENZIN, Norman, 1991, Images of Postmodern Society: Social Theory and Contemporary Cinema. London, Sage.

DENZIN, Norman, 1995, The Cinematic Society: The Voyeur's Gaze. London, Sage.

DESAI, Jigna, 2004, Beyond Bollywood. The Cultural Politics of South Asian Diasporic Film. New York, Routledge.

DESAI, Jigna, 2006, "Bollywood abroad: South Asian diasporic cosmopolitanism and Indian cinema”, in Gita Rajan and Shailja Sharma (eds.), South Asian American Cosmopolitanism. Palo Alto, CA, Stanford University Press, 115-137.

DIAS, Jorge, 1958, Missão de Estudos das Minorias Étnicas do Ultramar Português: Relatório da Campanha de 1957 (Moçambique e Angola). Lisboa, Centro de Estudos Políticos e Sociais da Junta de Investigações do Ultramar.

DICKEY, Sara, 1993, Cinema and the Urban Poor in South India. Cambridge, Cambridge University Press.

DOUGLAS, Mary, and Baron ISHERWOOD, 1996 [1979], The World of Goods: Towards an Anthropology of Consumption. London, Routledge.

DUDRAH, Rajinder, 2002, "Vilayati Bollywood: popular Hindi cinema-going and diasporic South Asian identity in Birmingham (UK)", Javnost - The Public: Journal of the European Institute for Communication and Culture, 9 (1): 19-36.

DUDRAH, Rajinder, 2006, Bollywood: Sociology Goes to the Movies. Delhi, Sage. 
EBRAHIM, Haseenah, 2008, "From 'ghetto' to mainstream: Bollywood in South Africa", Scrutiny2, 13 (2): 63-76.

GAONKAR, Dilip, 2001, Alternative Modernities. Durham, NC, Duke University Press.

GOPAL, Sangita, and Sujata MOORTI (eds.), 2008, Global Bollywood: Travels of Hindi Song and

Dance. Minneapolis, MN, University of Minnesota Press.

GOPALAN, Lalitha, 2002, Cinema of Interruptions: Action Genres in Contemporary Indian Cinema. London, British Film Institute.

GRAY, Gordon, 2010, Cinema: A Visual Anthropology. Oxford, Berg.

HALL, Stuart, 1980, “Cultural studies: two paradigms”, Media, Culture and Society, 2: 57-72. HANnerZ, Ulf, 1996, Transnational Connections: Culture, People, Places. London, Routledge.

HUGGAN, Graham, 1998, "Consuming India", Ariel: A Review of International English Literature, 29 (1): 245-258.

HUGGAN, Graham, 2001, The Postcolonial Exotic: Marketing the Margins. London, Routledge. KAO, Kai-Ti, and Rebecca-Anne DO ROZARIO, 2008, "Imagined spaces: the implications of song and dance for Bollywood's diasporic communities", Continuum: Journal of Media \& Cultural Studies, 22 (3): 313-326.

LAU, Lisa, and Ana Cristina MENDES (eds.), 2011 , Re-Orientalism and South Asian Identity Politics: The Oriental Other Within. New York, Routledge.

MAIRA, Sunaina, 2003, “TranceGlobal nation: Orientalism, Cosmopolitanism, and citizenship in youth culture”, Journal of Popular Music Studies, 15 (1): 3-33.

MAIRA, Sunaina, 2007, "Indo-chic: late capitalist Orientalism and imperial culture", in Mimi T. Nguyen and Thuy Linh Nguyen Tu (eds.), Alien Encounters: Popular Culture in Asian America, Durham, NC, Duke University Press, 22 1-243.

McGEE, Kristin, 2012, "Orientalism and erotic multiculturalism in popular culture: from princess Rajah to the Pussycat Dolls”, Music, Sound and the Moving Image, 6 (2): 209-238.

MILlER, Daniel, 1998, A Theory of Shopping. Cambridge, Polity Press/Cornell University Press.

MILLS, Wright, 2000 [1959], The Sociological Imagination. New York, Oxford University Press. MISIR, Deborah N., 1996, "The murder of Navroze Mody: race, violence and the search for order”, Amerasia Journal, 22 (2): 55-75.

MITCHELl, Timothy, 1989, "The world as exhibition", Comparative Studies in Society and History, 31 (2): 217-236.

NOVAK, David 2010, "Cosmopolitanism, remediation and the ghost world of Bollywood", Cultural Anthropology, 25 (1): 40-72.

PEREZ, Rosa Maria (ed.), 2006, Os Portugueses e o Oriente: História, Itinerários, Representações. Lisbon, Publicações Dom Quixote.

PRASAD, Madhava, 1998, Ideology of the Hindi Film: A Historical Construction. Delhi, Oxford University Press.

PUNATHAMBEKAR, Aswin, 2005, "Bollywood in the Indian-American diaspora: mediating a transitive logic of cultural citizenship“, International Journal of Cultural Studies, 8 (2): 151-173.

SAÏD, Edward W., 1995 [1978], Orientalism: Western Perceptions of the Orient. London, Penguin. SHRESTHOVA, Sangita, 2008, Between Cinema and Performance: Globalizing Bollywood Dance. Los Angeles, University of California, PhD thesis.

SHRESTHOVA, Sangita, 2011, Is It All about Hips? Around the World with Bollywood Dance. Delhi, Sage. 
SILVA, Ricardo O., 2012, O Cinema enquanto Identidade: Fronteiras da Modernidade Indiana através do Consumo de Cinema Bollywood. Lisbon, Lisbon University Institute, M.A. thesis. SKEY, Michael, 2013, "What does it mean to be cosmopolitan? An examination of the varying meaningfulness and commensurability of everyday 'cosmopolitan' practices", Identities: Global Studies in Culture and Power, 20 (3): 235-252.

TIRUMALA, Lakshmi, 2009, Bollywood Movies and Identity Construction amongst Second Generation Indian Americans. Lubbock, Texas Tech University, M.A. thesis.

TOOR, Saadia, 2000, "Indo-chic: the cultural politics of consumption in post-liberalization India”, SOAS Literary Review, 2: 1-33.

WACHINGER, Tobias, 2003, "Spicy pleasures: postcolonial India's literary celebrities and the politics of consumption", Ariel: A Review of International English Literature, 34 (2-3): 71-94.

WEENINK, Don, 2008, "Cosmopolitanism as a form of capital parents preparing their children for the globalizing world”, Sociology, 42 (6): 1089-1 106. 